University of Pennsylvania Carey Law School

Penn Law: Legal Scholarship Repository

Faculty Scholarship at Penn Law

$1-15-2003$

\title{
Prohibited Risks and Culpable Disregard or Inattentiveness: Challenge and Confusion in the Formulation of Risk-Creation Offenses
}

Paul H. Robinson

University of Pennsylvania Carey Law School

Follow this and additional works at: https://scholarship.law.upenn.edu/faculty_scholarship

Part of the Criminal Law Commons

\section{Repository Citation}

Robinson, Paul H., "Prohibited Risks and Culpable Disregard or Inattentiveness: Challenge and Confusion in the Formulation of Risk-Creation Offenses" (2003). Faculty Scholarship at Penn Law. 23.

https://scholarship.law.upenn.edu/faculty_scholarship/23

This Article is brought to you for free and open access by Penn Law: Legal Scholarship Repository. It has been accepted for inclusion in Faculty Scholarship at Penn Law by an authorized administrator of Penn Law: Legal Scholarship Repository. For more information, please contact PennlawIR@law.upenn.edu. 


\title{
Prohibited Risks and Culpable Disregard or Inattentiveness: Challenge and Confusion in the Formulation of Risk-Creation Offenses
}

\author{
Paul H. Robinson*
}

\begin{abstract}
Because they track the Model Penal Code, current criminal law formulations of risk offenses typically fail to distinguish the rule of conduct question-What risks does the criminal law prohibit?-from the adjudication question-When is a particular violator's conscious disregard of, or his inattentiveness to, a risk in a particular situation sufficiently condemnable to deserve criminal liability? Instead, the formulations address only the second question-through their definition of reckless and negligent culpability-and fail to provide a rule of conduct provision to define a prohibited risk.

This reliance upon culpability definitions as the core of risk-creation offense definitions is problematic because it fails to announce a useable conduct rule that describes those risks the law prohibits. Instead, this approach subjectivizes the definition of prohibited risks. What may be held "reckless" or "negligent" for one person may not be "reckless" or "negligent" for another person in the identical situation - an effect that strips case adjudications of their value in educating the community as to risks that the rules of conduct prohibit. Current risk-creation offenses also are problematic because they make results-including the creation of a prohibited risk-irrelevant to criminal liability. While this is consistent with the Model Code's view that resulting harm is insignificant, that only culpable state of mind ought to affect liability, it is inconsistent with the view of most state code drafters. Thus, while the Model Code grades offenses without regard to whether a prohibited risk in fact is created, most state codes logically would want to grade lower in the absence of a prohibited risk.

These two fundamental problems-the failure to distinguish conduct rules and adjudication rules and the confusion over the significance of results-are related. The Model Penal Code's general failure to distinguish conduct and adjudication rules made it less likely that state code drafters would notice what they would have seen as the Code's inappropriate subjectivization of risk and risk offenses. If the Model Code had systematically segregated conduct and adjudication rules, it would have been more obvious to state code drafters that the Code's formulation of risk-creation offenses was one that they could not accept.
\end{abstract}

\section{INTRODUCTION}

"A person is guilty of manslaughter/negligent homicide if he recklessly/negligently causes the death of another human being." This simple and common offense definition of risk-creation forms of homicide hides a variety of complex issues. Packaged into both the "recklessly" and the "negligently" requirements are two distinct questions: First, did the actor create a risk that the law prohibits, which resulted in death?

\footnotetext{
* Professor of Law, University of Pennsylvania. The author thanks Michael Moore, Ken Simons, George Fletcher, Leo Katz, Michael Cahill, and participants at the Cegla Conference on Negligence at Tel Aviv University for their very useful comments on this paper.
} 
Many risks, even of causing a death, are tolerated by the law — such as the risk inherent in driving a car or building a bridge. The second question concerns the actor's culpability: Given his purpose and his capacities, did the actor show conscious disregard of or inattentiveness to the risk he created? Was this disregard or inattentiveness sufficiently improper to deserve the condemnation of criminal conviction? Unfortunately, the standard formulation of American ${ }^{2}$ criminal law risk-creation offenses does not segregate these two questions - the question of prohibited risk versus the question of culpable disregard or inattentiveness - and thereby fails to allow criminal law to effectively perform its functions.

A second source of confusion and difficulty is the uncertainty over the significance of results. Should the actual creation of a prohibited risk matter in assessing criminal liability and grading? Or is actual risk-creation irrelevant? Is the only relevant fact an actor's subjective belief in facts that would suggest that a prohibited risk was created? In other words, do results matter, or just an actor's state of mind? These two views suggest different minimum requirements for criminal liability, as well as different principles for grading.

Yet American codes are hopelessly internally inconsistent in giving significance to results, as is apparent in their formulation of risk-creation offenses. In large part, the difficulty arises from a common failure of state code drafters to see that the model code they relied upon instantiates a view of the insignificance of results that conflicts with their own view that results do matter.

As will become apparent, these two sources of confusion in the formulation of risk-creation offenses are related.

\section{Two Functions of Modern Criminal Codes: Announcing Rules of Conduct and Defining Principles of Adjudication}

A criminal code of today must perform two very different functions: (1) it must perform the ex ante function of announcing the rules of conduct that are to govern the conduct of all persons within the code's jurisdiction; and (2) it must perform the ex post function of establishing for the participants in the criminal justice process the principles by which violations of the rules of conduct are to be adjudicated.

These two functions often are in tension with one another. Each calls for a different kind of code, addressed to a different audience, with different objectives: (1) To be effective ex ante, the rules of conduct must be formulated so that they can be understood and remembered and can be applied in daily life by laypersons having a wide range of capacities and having a wide variety of backgrounds. Effectiveness in announcing the rules of conduct requires simple, clear, and objective rules. (2) In

\footnotetext{
1 See, e.g., Model Penal Code $\S \S 210.1(1), 210.3(1)(a), 210.4(1)$ (1985).

${ }^{2}$ See a similar effect in the Israeli Penal Law $\S \S 21,304,1977$, S.H. 226.
} 
contrast, the goal of the principles of adjudication - to assess ex post the degree of liability and punishment, if any, due for a violation of the rules of conduct-often requires nuanced, subjective, and sometimes complex judgments, at least as nuanced, subjective, and complex as our notions of justice are (or as are the demands of whatever punishment theory is relied upon).

One might be disheartened by this conflict in the needs of a code's two functions, for it suggests a criminal code condemned to a permanent state of compromise. To serve one interest, the code must undermine the other. All that a drafter can do is attempt to strike a balance between the competing dysfunctions. But it turns out that no such compromise or balancing is necessary, because the doctrines that serve the rules-of-conduct function are distinct from those that serve the adjudication function. Thus, both functions can be maximized by simply identifying and segregating the doctrines that serve each one, then drafting the doctrines in a way that maximizes the effectiveness of their respective functions.

What does this segregation of doctrines look like? What doctrines make up the criminal law's rules of conduct? That is, what aspects of the criminal law are essential for a citizen to know if he or she is to know what the law commands? What doctrines are not necessary in order to know the law's commands, because they serve only to tell adjudicators whether and how much liability and punishment ought to be imposed ex post for a violation of the rules of conduct? A full working out of this segregation of criminal law doctrines appears in Part III of my book Structure and Function in Criminal Law. ${ }^{3}$

\footnotetext{
${ }^{3}$ Paul H. Robinson, Structure and Function in Criminal Law (1997). Let me sketch a few of the basic points. What doctrines are necessary to describe to citizens the conduct that the criminal law forbids, the conduct it requires, and the conduct that it permits because of special circumstances that otherwise would be forbidden? Looking first at offense definitions, the definition of forbidden conduct generally is found in the objective conduct and circumstance elements of a code's offense definitions. The culpability requirements of offense definitions typically serve the adjudication function - telling us whether performance of the forbidden conduct on this occasion ought to be punished and, if so, to what degree. (An important exception to this is the special kind of intention requirement contained in inchoate offenses.) In serving the adjudication function, the culpability requirements are supplemented by the excuse defenses, such as insanity, immaturity, involuntary intoxication, and mistake as to a justification. The objective result elements of offense definitions also serve the adjudication function, by establishing the grade of an offense, with greater punishment imposed where a forbidden result actually comes about than where it does not. (Not everyone agrees that this should be the rule, of course, but it is clearly the majority rule in the United States.) The rules of conduct specify not only what conduct is prohibited but also what is required. This aspect of the rules of conduct is found in the objective requirements of the law's duties to act. The principles for adjudicating violations of these duties are contained, again, in the culpability requirements for these duties and supplemented by the excuse defenses. They also include the special capacity requirement attached to omission liability. To illustrate, the rule of conduct requires parents to care for their children. If parents fail in this duty, the principles of adjudication examine whether their failure was purposeful, knowing, reckless, or negligent, whether the parents were capable of performing their duty, and whether their failure nonetheless might be excused.

Finally, the rules of conduct, to be complete, must tell citizens when they are permitted to engage in conduct that otherwise is prohibited. This aspect of the rules of conduct is found in the objective requirements of justification defenses. For example, the rules of conduct generally prohibit engaging in conduct that risks harm to another, yet the rules allow such conduct if it is necessary to defend against an unjustified attack.
} 
There are several instances, however, where the segregation of conduct rules and adjudication rules is not so easy, because the present doctrine's insensitivity to the practical importance of the distinction has led to an intertwining of the two functions within the same provision. The modern American criminal code's formulation of negligence rules is one of the more unfortunate of such instances.

\section{Mixing The Code's Two Functions in the Formulation OF Risk-Creation Offenses: Prohibited Risks versus CulPable DisRegard or INATTENTIVENESS}

In the realm of risk-creation offenses, a criminal code's two functions are these: (1) in order to articulate the rule of conduct, the code must give notice as to what risks are prohibited by the criminal law and what risks are not; and (2) to set its principles of adjudication for a violation of a rule of conduct, the code must describe the factors and standard for determining whether a given instance of disregard of or inattentiveness to a risk by a particular person is sufficiently culpable to warrant that person's condemnation by criminal conviction.

Admittedly, the first task (of giving notice of the risks that the criminal law prohibits) is a formidable one. It would be unwise to say simply, "No person shall engage in conduct that may cause injury to another person or damage to another's property." Some risks, even risks of personal injury to others, are tolerated by the criminal law. The criminal law prohibits and punishes only the creation of risks of a certain probability and of a certain severity of harm and under certain circumstances. If one builds a factory, drives to the theater, or opens an umbrella, one necessarily create risks to others that did not previously exist, yet we accept many of these risks as the necessary price for the advantages that a modern society gives us.

Substantial risk of minor harm is tolerated, as is minor risk of a more serious harm. The law uses a sliding scale between the two factors: the lower the probability, the greater the potential injury must be to reach the point of criminalization. In addition to probability and seriousness, the societal benefits of the risk also are relevant to whether it is criminalized. In an analysis analogous to justification defenses, we tolerate a more substantial risk if the benefits gained from the risk are sufficiently valuable. The risks

To summarize, the rules of conduct sought to be announced ex ante to the community are contained, for the most part, in the conduct and circumstance elements of offense definitions, the law's positive duties to act, and the (objective aspects of) justification defenses.

The principles of adjudication - telling participants in the criminal justice process how to judge a violation of the rules of conduct - are similarly dispersed throughout a criminal code's provisions. They are found in the objective result elements of offense definitions, most of the culpability requirements of offense definitions and duty provisions, and the excuse defenses. 
inherent in dynamiting may be justified in order to build a hospital, but the same risks might not be justified in order to entertain an explosives club. Whether a risk is justified is a function of the relative values the society gives to the competing interests. Thus, each assessment of risk-creation requires not only a judgment of probability and potential harm but also a balancing of competing community interests. ${ }^{4}$ While the law cannot give a precise description of every risk prohibited in every situation, it can at least identify for citizens these relevant factors and their interrelation so that those citizens can have some sense of what to think about with respect to creating risks.

Despite this need, modern American codes typically have no provision that describes, even in such general terms, the kinds of risks that are prohibited or even the factors that are relevant to defining a prohibited risk.

What codes typically do instead is to define reckless or negligent culpability. Recall the standard risk-creation homicide formulation quoted above: “A person is guilty of manslaughter/negligent homicide if he recklessly/negligently causes the death of another human being. The central determinant of liability — whether the death was "recklessly" or "negligently" caused — is governed by these widely adopted definitions of recklessness and negligence from the Model Penal Code:

Recklessly. A person acts recklessly with respect to a material element of an offense when he consciously disregards a substantial and unjustifiable risk that the material element exists or will result from his conduct. The risk must be of such a nature and degree that, considering the nature and purpose of the actor's conduct and the circumstances known to him, its disregard involves a gross deviation from the standard of conduct that a law-abiding person would observe in the actor's situation.

Negligently. A person acts negligently with respect to a material element of an offense when he should be aware of a substantial and unjustifiable risk that the material element exists or will result from his conduct. The risk must be of such a nature and degree that the actor's failure to perceive it, considering the nature and purpose of his conduct and the circumstances known to him, involves a gross deviation from the standard of care that a reasonable person would observe in the actor's situation. ${ }^{5}$

Thus, we learn that the Model Penal Code is not insensitive to the factors that ought to be relevant to determining whether a risk is prohibited. Look again:

A person acts recklessly/negligently with respect to a material element of an offense when he consciously disregards/should be aware of a substantial and unjustifiable risk that the material element exists or will result from his conduct. The risk must be of such a nature and degree that, considering the nature and purpose of the actor's conduct and the circumstances know to him, the actor's failure to perceive it involves a gross deviation from the standard of care that a law-abiding/reasonable person would observe in the actor's situation. ${ }^{6}$

\footnotetext{
${ }^{4}$ An actor may find some guidance in these calculations as to whether such a risk in such circumstances has been commonly tolerated in the past.

${ }^{5}$ Model Penal Code $\S 2.02(2)(\mathrm{c})$, (d).

${ }^{6} \mathrm{Id}$. (sections combined, emphasis added).
} 
The nature and degree of the risk and the benefits that may flow from it all are relevant under this provision. Further, these factors are to be assessed in light of the community's notion of the lawabiding/reasonable person standard of care. But while the Model Penal Code provision uses these factors, its formulation serves primarily to obscure a definition of a prohibited risk. To begin with, the provision quoted above is not a definition of what constitutes prohibited risk-creation, but rather is a definition of culpable disregard or inattentiveness to a risk. ${ }^{7}$ These are very different issues, as noted previously. This definition sets out that degree of conscious disregard or inattentiveness - as to either the risk of causing a prohibited result or the risk that an offense circumstance exists ${ }^{8}$ - that makes an actor's conduct blameworthy. The rule of conduct (What is the kind of risk an actor is prohibited from creating? ? $^{9}$ remains unaddressed. The Code may provide here an effective adjudication rule, but it fails to state a rule of conduct that people can use to govern their conduct in the future. An adjudication as to whether a person was (or was not) "reckless" or "negligent" - culpable disregard or inattentiveness—gives no guidance as to whether the risk in question is prohibited. It tells us only whether this defendant, given his knowledge and his capacities, was culpable for disregarding or being inattentive to the risk in this particular situation. Recall again the language of the "recklessly" and "negligently" definitions:

The risk must be of such a nature and degree that the actor's failure to perceive it, considering the nature and purpose of his conduct and the circumstances known to him, involves a gross deviation from the standard of care that a law-abiding/reasonable person would observe in the actor's situation. ${ }^{10}$

Thus, an actor may well create a prohibited risk, which the rules of conduct would want to announce to others as something they should avoid in a similar situation in the future, yet the actor may be held non-reckless and non-negligent and escape liability because, given his "purpose" or "the circumstances known to him" or his "situation" (which the drafters tell us is to be given a meaning broad enough to include some personal characteristics of the actor ${ }^{11}$ ), his disregard or inattentiveness to the risk

\footnotetext{
${ }^{7}$ See Paul H. Robinson, Rules of Conduct and Principles of Adjudication, 57 U. Chi. L. Rev. 729, 745-49 (1990).

${ }^{8}$ Culpable negligence can exist and therefore must be defined in relation to not only a risk of a prohibited result but also a risk that the circumstances are such that the actor's conduct is criminal. For example, it is this definition of culpable inattentiveness that is used to determine whether an actor's inattentiveness as to the age of a sexual partner was sufficiently culpable to be the basis for criminal culpability.

${ }^{9}$ The rule of conduct issue exists only with regard to risk-creation offenses, not circumstance offenses (which are discussed in Robinson, supra note 7). Where a prohibition is defined only in terms of conduct in certain circumstances, the circumstance either exists or it does not. One does not create a risk of a circumstance; one can only take a risk that a circumstance exists. Determining whether an actor has engaged in such mental riskinattentiveness is part of the liability function.

${ }^{10}$ Model Penal Code $\S 2.02(2)(d)$ (sections combined, emphasis added).

11 As the Code's commentary explains:

A further point in the Code's concept of negligence merits attention. The standard for ultimate judgement invites consideration of the "care that a reasonable person would observe in the actor's
} 
is not culpable. Or, it may be that his disregard or inattentiveness under the circumstances was wrong but not wrong enough - not a "gross deviation" from the standard of care of a law-abiding/reasonable person - to merit the condemnation of criminal conviction. Thus, where a prohibited risk is created, a defendant may nonetheless be held non-reckless and non-negligent under the Code, thus sending the opposite rule-of-conduct message than that intended regarding whether the risk at hand is a prohibited risk that persons are to avoid creating in the future.

Just as there can be a prohibited risk but no culpable disregard or inattentiveness, so too can there be a non-prohibited risk yet a finding of culpable disregard or inattentiveness, and, thus, liability, under the Code's formulation, again sending the opposite rule-of-conduct message intended. More on this reverse case in a moment. ${ }^{12}$

Even if citizens and courts were able to dissect the "recklessly" and "negligently" definitions, to pull from them the relevant factors and analysis (the nature, degree, and justification of the risk and the community's balance of these as manifested in the standard of conduct of the reasonable person) and to use them to mentally construct a definition of a prohibited risk, the Code would still fail in its function of defining prohibited risk, because the Code's recklessness and negligence definitions are applicable only where an offense criminalizing risk-creation uses one of those terms. This is sometimes the case, as in homicide. ${ }^{13}$ But more frequently, the Code defines risk-creation offenses as prohibiting simply a "substantial risk" or just a "risk" or a "danger" of a particular harm, using different phrases in different contexts. ${ }^{14}$ The effect of this is to leave out of the prohibited-risk analysis consideration of most of the factors the Code drafters themselves seem to agree are relevant: the nature, degree, and justification of the

situation." There is an inevitable ambiguity in "situation." If the actor were blind or if he had just suffered a blow or experienced a heart attack, these would certainly be facts to be considered in a judgement involving criminal liability, as they would be under traditional law. But the heredity, intelligence or temperament of the actor would not be held material in judging negligence, and could not be without depriving the criterion of all its objectivity. The Code is not intended to displace discriminations of this kind, but rather to leave the issue to the courts.

Model Penal Code $\S 2.02 \mathrm{cmt} .4$ at 242.

${ }_{12}$ See infra Part V.

13 A person is guilty of negligent homicide "if he negligently causes the death of another human being." Model Penal Code $\S \S 210.1(1), 210.4(1)$; see also id. $\S 211.1(1)(b)$ : "A person is guilty of assault if he negligently causes bodily injury to another with a deadly weapon ...." Id. §220.3(1)(a): "A person is guilty of criminal mischief if he damages tangible property of another ... by negligence in the employment of fire, explosives, or other dangerous means ...."

${ }^{14}$ For example, the Code prohibits creation of a "substantial risk" of causing death (in section 211.1(2)(a), aggravated assault; "serious bodily harm" is defined in section 210.0(3)), creation of a "danger" of death or a "substantial risk" of death (in section 211.2, endangerment), creation of a "substantial risk" of loss of entrusted property (in section 224.13), and creation of a "danger" of damage or destruction of a building (in section 220.1(2)(b), reckless burning or exploding). The Code prohibits the "risk" of causing terror or serious public inconvenience (in section 211.3, terroristic threats). Also prohibited are a "risk" of causing a "substantial risk" of 
risk and the community's balance of these as manifested in the standard of care of the reasonable person. The term "risk" alone might be taken to criminalize any risk; "substantial risk" might be taken to focus only on the degree of the risk (or possibly its nature); nothing in the language suggests the need to assess the justification of the risk-creation or the balance of competing interests.

The effect of the Code's failure to provide guidance in defining prohibited risks might seem to be minimized where the Code prohibits the most egregious risk-creation through offenses that require the actual harm to occur, as in homicide offenses. That is, if an actual result is required, it might be argued, we avoid the problem of having to define when a mere risk will be criminal. But as most thoughtful readers have already discerned, requiring that the actual harm has occurred does not avoid the need to determine whether the risk was criminal. ${ }^{15}$ By defining manslaughter and negligent homicide to require a result of death, for example, one does not avoid the need to determine whether the actor's conduct in causing that death created a risk that was criminal. If the risk was not prohibited, on what ground could the law base liability for homicide?

Indeed, the need for a clear rule for assessing whether the risk was prohibited is all the more important in cases of actual harm because of the human tendency to exaggerate the degree of a risk when the risk comes to fruition. The empirical literature reports the common phenomenon of persons significantly overestimating the extent of a risk if the harm risked actually occurs. ${ }^{16}$ This phenomenon may lead to liability when in reality the risk created was not criminal. Death will occur in cases where the risk created is sufficiently low as to be non-criminal, and there ought to be no liability in these cases. Yet, without a definition of what constitutes a prohibited risk, how can this determination be made?

Thus, the Code's reliance on the "recklessly" and "negligently" definitions, rather than a provision defining prohibited risk, not only frustrates the Code's ex ante rule articulation function but also distorts its ex post adjudication function by perverting its liability rules for risk-creation offenses. Specifically, the Code's subjectivization of the offense (criminalizing not the creation of a prohibited risk but rather an actor's disregard or inattentiveness to it) allows criminal liability for reckless and negligent offenses even in the absence of a prohibited risk. More on this in Part V, where we will see that this

death, through restraint (in section 212.2(a), felonious restraint) and a "risk" of causing a catastrophe (in section 220.2(2), risking catastrophe).

15 The use of result offenses to punish prohibited risk-creation not only does not avoid the need to define a prohibited risk but also creates several other special problems of its own. For example, the resulting array of overlapping offenses may define the prohibited risk differently. In some instances of overlap between result and risk-creation offenses, the conduct creating a risk is prohibited and punished only if the harm comes about, but whether the harm will occur is a fact that the actor cannot know at the time he engages in the conduct. See Robinson, supra note 7 , at 748-49.

16 Baruch Fischoff, Hindsight Does Not Equal Foresight: The Effect of Outcome Knowledge on Judgment Under Uncertainty, 1 J. Experimental Psychol. 288, 298 (1975). 
subjectivization of the definition of crime by the Model Penal Code is entirely consistent with the Code's criminalization philosophy, which focuses on actualized culpability and minimizes the significance of results, but is inconsistent with the philosophy of most state codes.

\section{Defining Prohibited Risks: A Proposal}

Making use of the language of the Model Penal Code, one can construct provisions that more effectively perform both a code's rule articulation function and its adjudication function. A definition of a prohibited risk might look something like this:

An actor creates a "prohibited risk" when he creates a substantial and unjustified risk that a prohibited result will occur. A risk is substantial and unjustified if, given its nature, degree, and circumstances, its creation is a deviation from the standard of care of a reasonable person. ${ }^{17}$

Or, using language other than that of the Model Code, one might construct a provision something like this:

A "prohibited risk" is a risk that is of such a likelihood and of such a harm that the reasonable person would not judge it justified by the circumstances.

Risk-creation homicides, then, could be defined as follows:

An actor commits manslaughter/negligent homicide if, with recklessness/negligence as to causing the death of another human being, he creates a prohibited risk of death from which death results.

Of course, one can avoid such a stilted definition by having a general principle that liability for a riskcreation offense requires proof that the prohibited risk in fact was created. For example:

Risk-Creation Offenses. An actor may not be held liable for a risk-creation offense without proof that he created a prohibited risk. Nothing in this Section bars liability for an inchoate offense.

${ }^{17}$ One can construct a culpability definition, again using Model Penal Code language, as follows (remember that the culpable risk-inattentiveness terms must be defined with respect to both result and circumstance elements): A person acts "negligently" with respect to an element of an offense when he should be aware of a risk that the circumstance exists or that his conduct will cause the result, as the case may be. The risk must be of such a nature and degree that, considering the nature and purpose of the actor's conduct and the circumstances known to him, the actor's failure to perceive it involves a gross deviation from the standard of care that a reasonable person would observe in the actor's situation.

The only real change to the Code's current culpability definitions is deletion of the phrase "substantial and unjustified" that modifies the term "risk" in the first sentence of the definition in the Code. The substantiality and justifiability of the risk are matters of concern in defining prohibited risk-creation, but they add nothing to the definition of culpable risk-inattentiveness that is not already covered by the culpability definition's call, in the second sentence, to judge the blameworthiness of the actor's disregard or unawareness of the risk. Presumably, juries will more easily find "a gross deviation" where the risk is more "substantial" or more "unjustified." 
With such a principle (which courts could supply even in the absence of a statutory provision) and a definition of a prohibited risk, one can define risk-creation/negligent homicide in its standard form, as simply "recklessly/negligently causing the death of another human being."18

To conclude, my claim here is not that the Model Penal Code drafters are insensitive to factors that are important to the definition of prohibited risk-creation. There seems little more that a code can do in defining a prohibited risk than to identify the relevant factors and the standard, in much the same language that the Model Code uses. My claim here is rather that by failing to see the issues of prohibited risk and culpable disregard or inattentiveness as distinct, the Code's "recklessly" and "negligently" culpability definitions are ineffective in announcing an effective rule of conduct for prohibited risks.

${ }^{18}$ In Robinson, supra note 3, apps. A, B, I propose the following formulations as part of a larger recodification that would create a separate code of conduct and a code of adjudication:

\section{SECTION 3. INJURY TO A PERSON}

\section{From the Code of Conduct}

You may not cause bodily injury or death to another person.

SECTION 24. DAMAGE TO OR THEFT OF PROPERTY

You may not damage, take, use, dispose of, or transfer another's property without the other's consent. Property is anything of value, including services offered for payment and access to recorded information.

SECTION 51. CREATING A ProhiBited Risk

You may not act in a way that creates a substantial and unjustified risk of causing a result made criminal by this Code, EXCEPT that conduct creating a risk that would otherwise be a crime is not a crime if it is:

(a) commonly engaged in, AND

(b) generally thought by the community at large to be lawful.

From the Code of Adjudication

SECTION 113. ReQuirements For Violation of CODE OF CONDUCt SECTION 51 (CREATING A PROHIBITED RisK)

An actor violates Code of Conduct Section 51 (Creating a Prohibited Risk) if, given the nature, degree, and circumstances of the risk, its creation is a gross deviation from the standard of conduct of a law-abiding person.

SECTION 401. DEFINITIONS

For the purposes of this Code of Adjudication:

$\cdots$

(3) A person acts 'recklessly' with respect to an element of a violation when he or she consciously disregards a risk that the element exists or will result from his or her conduct. The risk must be of such a nature and degree that, considering the purpose of the actor's conduct and the circumstances known to him or her, the actor's conscious disregard of it involves a gross deviation from the standard of conduct that a law-abiding person would observe in the actor's situation.

(4) A person acts 'negligently' with respect to an element of a violation when he or she should be aware of a risk that the element exists or will result from his or her conduct. The risk must be of such a nature and degree that, considering the purpose of the actor's conduct and the circumstances known to him or her, the actor's failure to perceive it involves a gross deviation from the standard of conduct that a law-abiding person would observe in the actor's situation. 


\section{The Model Penal Code and the Significance of Results}

A second sort of difficulty in the formulation of risk-creation offenses arises from states' failure to appreciate the full implications of the Model Penal Code drafters' view that results ought to be irrelevant to criminal liability, that only acted upon culpability ought to be relevant. The Model Code's formulations generally are consistent with its underlying philosophy. It is the state code drafters using the Model Code, who generally disagree with the Code's view of results (most states think results are highly relevant to criminal liability), that have created the problems: the state drafters have produced flawed state codes by failing to fully neutralize the many ways in which the Model Code drafters made results insignificant.

The most obvious provision implementing the Model Penal Code view that the actual occurrence of a result ought to be insignificant, that an actor's liability ought to depend only on his conduct and culpable state of mind, is section 5.05(1):

Except as otherwise provided in this Section, attempt, solicitation and conspiracy are crimes of the same grade and degree as the most serious offense which is attempted or solicited or is an object of the conspiracy. An attempt, solicitation or conspiracy to commit a [capital crime or a] felony of the first degree is a felony of the second degree. ${ }^{19}$

Thus, except for attempted murder and attempted aggravated rape, all other attempts (for example, attempted arson, attempted sexual assault) are punished the same as is the completed offense. Another example of the Code's philosophy is its complicity provision, which treats unsuccessful attempts to aid a perpetrator as complicity, for which full substantive liability is imposed. ${ }^{20}$

The Code's view that attempts generally ought to be of the same grade as the completed offense is consistent with its focus on an actor's conduct and culpable state of mind. That focus reflects the Code's dominant concern for an actor's dangerousness. An offender is no less dangerous because a harmful result intended or risked is fortuitously avoided. ${ }^{21}$ The drafters explain:

The theory of this grading system may be stated simply. To the extent that sentencing depends upon the antisocial disposition of the actor and the demonstrated need for a corrective sanction, there is likely to be little difference in the gravity of the required measures depending on the consummation or the failure of the plan. ${ }^{22}$

\footnotetext{
19 Model Penal Code $\S 5.05(1)$.

${ }^{20}$ Id. $\S 2.06(3)(\mathrm{a})(\mathrm{ii})$. See Paul H. Robinson, Criminal Law $\S 6.1$ (1997) (“Objective elements under modern codes").

${ }^{21}$ See Stephen J. Schulhofer, Harm and Punishment: A Critique of Emphasis on the Results of Conduct in the Criminal Law, 122 U. Pa. L. Rev. 1497, 1514-16 (1974).

${ }^{22}$ Model Penal Code $\S 5.05(2) \mathrm{cmt}$. at 490.
} 
The person who attempts the offense but fails - the intended victim happens to move just before the bullet is fired - is no less dangerous by virtue of the failure. ${ }^{23}$ (Similarly, in the context of complicity, the unsuccessful accomplice is no less dangerous by virtue of his failure actually to assist a perpetrator.)

While the Code drafters can justify their disregard of results, the majority of American jurisdictions apparently are unpersuaded by the arguments to do so. A majority of American codes reduce the grade of an actor's liability if the harm or evil of the offense does not occur. ${ }^{24}$ This is true even of modern American codes that are highly influenced by the Model Penal Code in other respects. ${ }^{25}$ Giving significance to results is consistent with a blameworthiness rationale if, as most people accept to be the case, the occurrence of a prohibited result increases an actor's blameworthiness, other things being equal. ${ }^{26}$ Thus, a jurisdiction following a blameworthiness rationale would grade an inchoate offense less than the substantive offense. (And such a blameworthiness rationale would permit only attempt liability for an accomplice who tries but fails to assist. ${ }^{27}$ )

The broad rejection of the Code's indifference to results may be explained in part by a strong intuitive sense that results are significant, at least in assessing the degree of an actor's blameworthiness.

The notion that there should be a difference in punishment is deeply rooted in the popular conscience, and to ignore it is to risk jury nullification. ... The successful criminal and the person who engaged in an unsuccessful attempt are in some sense not of equal culpability. They are different in that the defendant who succeeded in his purpose has done an injustice to another; he has brought about an objective evil in the form of an injury to another; he has actively participated in the cruelty and tragedy of life. He has done a worse act than the person who failed and is in some sense a worse man. It is this largely intuitive judgment that finds expression in existing law. ${ }^{28}$

This description of the intuition of laypersons is supported by empirical studies. ${ }^{29}$

23 See Robinson, supra note 20, 33.3 ("Arguments against giving significance to resulting harm"); id. $§$ V.1 ("The significance of resulting harm"); id. §11.2 ("Conflicting views").

${ }^{24}$ See Paul H. Robinson, The Role of Harm and Evil in Criminal Law: A Study in Legislative Deception?, 5 J. Contemp. Legal Issues 299, 305 n.18 (1994) [hereinafter Robinson, Harm and Evil]; see also authorities collected at Paul H. Robinson, Fundamentals of Criminal Law 488-89 (1988).

${ }_{25}$ See, e.g., Cal. Penal Code $\S$ 664a (West 1999); Ill. Comp. Stat. ch. 38, ๆ 8-4(b); N.J. Stat. Ann. § 2C: 3-11; N.Y. Penal Law § 10.00(11); Wash. Rev. Code Ann. § 9A.08.020 (West 1988).

${ }^{26}$ Some scholars dispute this point. See Robinson, supra note 20, § 3.2 ("Arguments against giving significance to resulting harm").

27 Many jurisdictions modeling their codes after the Model Penal Code do drop or alter this aspect of the Code's complicity provisions (Model Penal Code $\S \S 2.06(3)(a)(i i), 5.05(1)$ (1985)). See, e.g., Colo. Rev. Stat. $\S 18-1-603$ (1990); Minn. Stat. Ann. § 609-05 (West 1987); Wash. Rev. Code Ann. § 9A.08.020 (West 1988).

28 John H. Mansfield, Hart and Honoré, Causation in the Law-A Comment, 17 Vand. L. Rev. 487, 494-95 (1964) (summarizing explanation given by Hart and Honoré).

29 See Paul H. Robinson \& John M. Darley, Justice, Liability, and Blame: Community Views and the Criminal Law, Studies 1 \& 17, at 14-28, 181-89 (1995). 
One may wonder whether the Model Penal Code's exception for a first-degree felony ${ }^{30}$ is inconsistent with its theory for the remainder of the provision. If the arguments for grading an attempt the same as the substantive offense are sound, why should they not apply equally to first-degree felonies? ${ }^{31}$ One might speculate that the drafters had a good political reason for permitting the exception: Murder and aggravated rape are perhaps the two most serious offenses, and therefore will receive the greatest public attention. Grading attempt the same as the offense in these cases would create a highly public display of the Code's failure to mirror community notions of desert. The drafters might have feared that giving identical treatment to a case where there is a death and a case where there is no death, or to a case where there is a rape and a case where there is no rape, could open the criminal law to ridicule as being hopelessly out of touch with the community notions of justice, and this, in turn, could reduce the criminal law's crime control effectiveness. ${ }^{32}$

That the first-degree offense exception has effect in few cases might lead one to conclude that generally the Code adheres to its principle that results are insignificant to liability. But the fact is that the entire Code is suffused with inconsistency on the issue. A variety of select offenses have been defined and graded to distinguish the case of no harm or evil from the case where a harm or evil occurs. Note the dramatic difference in grading between manslaughter, a second-degree felony, and endangerment, a misdemeanor. ${ }^{33}$ The actor's conduct and culpability may be identical, yet the offense for which he is liable will vary, as will the grade, solely according to whether the risk created results in a death. Similarly, recklessly causing a catastrophe is a third-degree felony; the same recklessness is punished as a misdemeanor where the catastrophe does not occur. ${ }^{34}$ If results are insignificant, as the drafters insist in their grading of inchoate conduct, why are offenses often defined to create a greater grade of liability only because of the occurrence of results? In fact, if results are not significant, why does the Code distinguish

30 Model Penal Code $\S 5.05(1)$. See Robinson, supra note 20, $§ 11.2$ ("Exception for first degree felonies").

31 The commentary offers a deterrent efficiency explanation.

It is doubtful ... that the threat of punishment for the inchoate crime can add significantly to the net deterrent efficacy of the sanction threatened for the substantive offense that is the actor's object, which he, by hypothesis, ignores. Hence, there is a basis for economizing in use of the heaviest and most afflictive sanctions by removing them from the inchoate crimes. The sentencing provisions for second degree felonies, including the provision for extended terms, should certainly suffice to meet whatever danger is presented by the actor.

Model Penal Code $\S 5.05(2) \mathrm{cmt}$. at 490. But if such economizing is wise for attempts toward first-degree offenses, why is it not equally wise for all inchoate offenses? Why should we think that the "threat of punishment for the inchoate crime can add significantly to the net deterrent efficacy of the sanction threatened for the substantive offense" of a second-degree or less serious offense? There are serious issues about the deterrent effect of official criminal sanction. There are even greater reasons to be doubtful about the deterrent effectiveness of such micromanipulation of doctrine, such as this.

32 See generally Paul H. Robinson \& John M. Darley, The Utility of Desert, 91 Nw. U. L. Rev. 453 (1997).

33 Compare Model Penal Code $\S \S 210.3(1)(\mathrm{a}), 210.3(2)$, with id. $\S 211.2$.

34 Compare id. § 220.3(1), with id. § 220.3(2). See Robinson, Harm and Evil, supra note 24, at 316. 
an attempt from a completed offense? That is, why not define all offenses as "An actor is liable for [the offense] if he does or attempts to do ..."? Why does complicity liability require that the perpetrator actually performed the conduct constituting the offense $?^{35}$ Why is a strict "but for" causation test required before an actor can be held accountable for a result, rather than some less demanding causal connection? ${ }^{36}$ Why are result elements ever required in the definition of offenses? ${ }^{37}$

The answer in each instance may be a political one, signaled above: a criminal law ignoring the occurrence of actual results would be perceived as so counterintuitive as to lose credibility. The instances where the Model Penal Code drafters have elected to compromise on their view that results ought to be irrelevant are typically instances, like homicide or causing catastrophe, where their unpopular view of results would be highlighted and most likely to cause public stir.

Some writers have pointed out that the criminal justice system operates effectively only with the cooperation and acquiescence of those who participate in the system, on both sides of the law, and that cooperation and acquiescence exist only because the criminal law is generally perceived as just and fair. ${ }^{38}$ Others have suggested that the most effective criminal law compliance mechanism is not the threat of incarceration or fine, but rather the threat of moral disapproval and the appeal of doing right. Further, the degree of the criminal law's power in gaining compliance is a function of the strength of its moral credibility. ${ }^{39}$ To deviate from the community's perception of just desert, then, is to injure to some extent the criminal law's ability to gain future compliance. Note that these are utilitarian arguments, as are the Code's arguments for opposing the significance to results. But contrary to the Code's conclusion, these arguments suggest that the most efficient means of reducing future crime is to distribute liability according to each actor's desert as perceived by the community. ${ }^{40}$

A cynic might suggest that the Model Penal Code drafters are simply very smart. They understand the importance of community acceptance and, therefore, have created the illusion that the occurrence of results matters in the Code. But, in fact, they undercut the significance of results in less obvious ways. For example, they create a structure that distinguishes completed offenses from attempts, as if the difference matters; then, having provided the facade that the public expects, they are free to

\footnotetext{
${ }_{35}$ Model Penal Code $§ 2.06(7)$. See Robinson, supra note 20, $§ 6.1$ ("Complicity and debate over significance of harm").

${ }^{36}$ Model Penal Code $\S 2.03$.

${ }^{37}$ For example, result elements are found in offenses such as criminal homicide (Model Penal Code $§ 210.1$ ), rape and related offenses (Model Penal Code § 213.1), and arson and related offenses (Model Penal Code $\S 220.1$ ). For a more detailed discussion of the Code's inconsistencies on this matter, see generally Robinson, Harm and Evil, supra note 24 , at 312-15.

38 Louis Michael Seidman, Soldiers, Martyrs, and Criminals: Utilitarian Theory and the Problem of Crime Control, 94 Yale L.J. 315 (1984).

39 See Robinson \& Darley, supra note 29; Robinson \& Darley, supra note 32.
} 
include a provision like Model Penal Code section 5.05(1), which, in one sentence, eviscerates the grading difference between attempts and substantive offenses. ${ }^{41}$ The danger, of course, is that if the deception is discovered, the loss of credibility may damage the criminal justice system's credibility more seriously than more openly denouncing the significance of results ever would. ${ }^{42}$

\section{CONFUSION OVER THE SignificANCE OF RESUlTS IN THE FORMULATION OF RISK-CREATION OFFENSES}

\section{A. Ignoring Objective Risk-Creation by Criminalizing Only Subjective Risk-Taking (Recklessness)}

The Model Penal Code's view of results - that they ought not be significant to criminal liability-is apparent in the Code's formulation of risk-creation offenses. Consider a single-parent law professor scheduled to bring his children with him to a conference in Israel. Television reports from the area show what is essentially a war zone. He is anxious to attend the conference, however, so he disregards the serious risk to his children and goes to the conference as planned. Once he arrives, he realizes that all of the violence is in Ramallah and that there is no danger of violence in Tel Aviv, the site of the conference. Having never been to Israel, he had incorrectly assumed that the Ramallah violence threatened Tel Aviv. His children are not and never have been in danger.

If he is charged with reckless endangerment, should he be liable? I assume most people would say no. He did not put his children in danger; he only mistakenly believed that he had. Would he be liable for reckless endangerment under the Model Penal Code and those codes that follow its lead? Yes. (Indeed, if his children were killed unexpectedly by terrorists, and assuming he has a duty as a parent not to risk his children by bringing them to a war zone, he might well be liable for manslaughter.) The reason for this liability result is found in the Code's definition of "recklessly," which does all the work in defining reckless risk-creation offenses. (Manslaughter requires only proof that the actor "recklessly caused" another's death. ${ }^{43}$ ) The definition of "recklessly" does not require that the actor actually create a prohibited risk; in the Model Penal Code's preference for the subjectivization of crimes, it is enough that he thinks he is creating a prohibited risk. Recall the definition:

Recklessly. A person acts recklessly with respect to a material element of an offense when he consciously disregards a substantial and unjustifiable risk that the material element exists or will result from his conduct. The risk must be of such a nature and degree that,

\footnotetext{
40 See generally Robinson, supra note 20, 1.2 ("Compliance power as function of moral credibility").

41 The text of Model Penal Code section 5.05(1) is quoted in supra text accompanying note 19.

42 For further discussion of the dangers of deception in this context, see Robinson, Harm and Evil, supra note 24, at 315-22.

${ }^{43}$ Model Penal Code 210.3(1)(a). Similarly, the Code's version of the endangerment offense is satisfied if one engages in conduct that places "or may place" another in danger. Id. $\S 211.2$, quoted in infra text accompanying note 62.
} 
considering the nature and purpose of the actor's conduct and the circumstances known to him, its disregard involves a gross deviation from the standard of conduct that a law-abiding person would observe in the actor's situation. ${ }^{44}$

The law professor did "consciously disregard" a substantial and unjustified risk that his conduct would cause the prohibited result: injury or death to his children.

One might argue that by requiring that the actor consciously disregard "a substantial and unjustified risk," the definition presumes that such a risk in fact exists. I agree. But what "risk" is it that must exist? There is no such thing as a risk in a tangible sense, as there is a death or an injury. A risk exists only as an ex ante perception of a chance of harm. And it is not just any ex ante perception. To the omniscient observer, for example, there is no such thing as a risk, even ex ante. Either the harm will occur or it will not. A risk can exist only for the ex ante observer with imperfect knowledge.

A risk could be assessed from a variety of non-omniscient perspectives: for example, from the ex ante perspective of an observer knowing everything a human can know ${ }^{45}$ or from the perspective of the reasonable person observing the objective surroundings and objective events up to that moment. What perspective are we to take in giving meaning to the "risk" that the Model Penal Code requires that the actor consciously disregard? The Code tells us in the second sentence of the above quoted "recklessly" definition.

[A risk] of such a nature and degree that, considering the nature and purpose of the actor's conduct and the circumstances known to him, its disregard involves a gross deviation from the standard of conduct that a law-abiding person would observe in the actor's situation. ${ }^{46}$

This is a version of the reasonable person standard, but individualized with the italicized language. Under this individualized objective standard, the law professor did "consciously disregard" a risk as the Code defines "risk" - that is, a risk from the perspective of "the circumstances known to [the actor]."

The same analysis applies to more mundane situations. Consider the actor driving past a school where children are out on the playground for recess. A posted sign states the rule of conduct: 30 miles per hour if the children are out for recess; $50 \mathrm{mph}$ if they are not (based on the calculation that driving 50 mph past the school would be a "gross deviation from the standard of care of a law-abiding person" if children were out for recess, but would not be a "gross deviation" if they were not out). The actor drives

\footnotetext{
44 Model Penal Code $\S 2.02(2)(\mathrm{c})$.

45 Some things are unknowable, such as the exercise of free will (for those who believe in it) and events that are the product of complexity beyond human comprehension and calculation producing what, from the human perspective, are essentially random events.

46 Model Penal Code $\S 2.02(2)$ (c).
} 
$50 \mathrm{mph}$ past the school, even though he believes the children are out for recess. He is reckless as to injuring a child under the Model Penal Code definition.

But assume that in fact he is mistaken about the situation. The children are actually in school, not out; thus the children were not in fact ever endangered. Is the actor nonetheless liable for reckless endangerment? Yes, under the Code. If he accidentally strikes and kills an errant student who has skipped school, is he liable for manslaughter? Yes, again, under the Code. He will be liable- he consciously disregarded a substantial and unjustified "risk," as the Code defines it — even though he did not actually create a prohibited risk.

If the prohibited risk were defined as an objective rule of conduct, as proposed in Part III, it would be clear that no prohibited risk has been created, and thus, there would be no manslaughter liability for the death. The actor could conceivably be liable for attempted manslaughter, if there were such an offense, or attempted endangerment, where there is no resulting death. ${ }^{47}$ The punishment of impossible attempts is designed to capture just such instances as this, where, if the circumstances were as he believes them to be, the actor would be committing the offense. (Note that the reverse situation arises with regard to liability for the unknowingly justified actor. The Code's subjectivization gives no defense, thus imposing full substantive liability, but an objective formulation of justification defenses would provide only impossible attempt liability. ${ }^{48}$ )

\section{B. Ignoring Objective Risk-Creation by Criminalizing Only Culpable Inattentiveness to Risks (Negligence)}

A similar, but slightly different, analysis applies to the Code's treatment of negligence offenses, by which the Code punishes culpable inattentiveness to, rather than conscious disregard of, a prohibited risk. Assume the driver going past the schoolyard has a broken speedometer, which registers 50 miles per hour when he is actually going only $30 \mathrm{mph}$. Thus, as he approaches the schoolyard, he mistakenly believes he is going $50 \mathrm{mph}$. He nonetheless pays no attention to whether there are children out for recess. If the facts were as he believes (if he were in fact going $50 \mathrm{mph}$ ), then his inattentiveness to the children would clearly constitute negligence, and if he killed a child, he would be liable for negligent homicide. Where he only mistakenly believes he is going $50 \mathrm{mph}$, but in fact is going only $30 \mathrm{mph}$, is he liable for negligent homicide under the Code? Yes, even though his conduct does not in fact create an objective prohibited risk. He "negligently" caused the death, under the Code's individualized reasonable person standard.

\footnotetext{
47 Several states allow such liability, and as I have argued elsewhere, there are good policy reasons in support of it. Robinson, supra note 20, at 636-39.

${ }^{48}$ See Robinson, supra note 3, at 108-15.
} 
Negligently. A person acts negligently with respect to a material element of an offense when he should be aware of a substantial and unjustifiable risk that the material element exists or will result from his conduct. The risk must be of such a nature and degree that the actor's failure to perceive it, considering the nature and purpose of his conduct and the circumstances known to him, involves a gross deviation from the standard of care that a reasonable person would observe in the actor's situation. ${ }^{49}$

The actor was not aware of a substantial and unjustified risk to the children, but he should have been aware of such a "risk," at least as that term is defined by the Code as an individualized objective standard. Given "the circumstances known to him"—driving past the schoolyard going $50 \mathrm{mph}$ - the Code's notion of a "substantial and unjustified risk" exists, and he should have paid attention to whether the children were or were not out for recess. His inattentiveness to that fact makes him negligent under the Code. Thus, if he accidentally kills an out-of-school student, he is liable for negligent homicide even though he did not in fact create an objective prohibited risk.

If a prohibited risk were defined as an objective rule of conduct, as proposed in Part III, it would be clear that no prohibited risk has been created here and, thus, there would be no liability for the actor. (He could conceivably be held liable for attempted negligent homicide, if there were such an offense, for the punishment of impossible attempts is designed to capture just such instances of a mistaken belief in circumstances that, if true, would make his conduct an offense.)

\section{Should Results (and Objective Risks) Matter?}

One might argue that the Model Penal Code has it right, that there is little reason to reduce the actor's liability because of facts unknown to him (i.e., the absence of an objectively-determined prohibited risk). Under the circumstances as he believes them to be, he consciously disregarded a prohibited risk of death, in the case of recklessness, and was culpably indifferent to a prohibited risk, in the case of negligence. Why should the lucky absence of a prohibited risk eliminate his liability or reduce it to that of an attempt? The answer, of course, is the same as it is to all similar questions regarding the significance of results when tangible harms are at issue. There we ask: If his culpability and conduct remain the same, why should it reduce an actor's liability that a resulting harm does not in fact occur? Whatever reasons one gives in answer to that question - and there are many different kinds of answers - the same answers are appropriate here. Of course, if one does not believe in the significance of results elsewhere, there is little reason to think them significant here.

It makes sense for the Model Penal Code drafters to not care whether an objective prohibited risk actually exists. Their focus, where they can get away with it, is exclusively on the actor's conduct and

49 Model Penal Code $\S 2.02(2)(d)$. 
culpability, not his conduct's results. While the drafters may not be able to afford to ignore the tangible and highly publicized result of a death, they can get away with ignoring the intangible result of whether an actor's conduct creates or increases an objective risk.

\section{Is an Objective Risk a Result?}

One might argue that a risk - even an objective risk - is not a harm, and therefore, there is little reason to draw an analogy between the two. But while an objective risk is not a harm, it is a result, and more importantly, it is a result that deserves to be prohibited and punished in the same way that a harm is.

The driver who is in fact driving 50 miles per hour past a schoolyard with the children out for recess is increasing the (ex ante) chance of injury to a child over what would exist if he were driving only $30 \mathrm{mph}$. And that increase in the chance of injury is enough to cross the line from a tolerated risk to a prohibited risk. The increased objective risk is not just a matter of subjective perception by the actor, but a factual statement of existing conditions. Yes, it is true that the added "risk" is not a physical injury but, rather, an ex ante evaluation of a probability of injury. But that only means it is an intangible "harm"-a sort common in criminal law. If 1000 drivers pass by at 50 miles per hour and 1000 drivers pass by at 30 miles per hour, we can expect more children to be injured or killed by the first group than by the second group. The world is a worse place for the first kind of conduct than for the second. The world is not made a worse place by the driver going by at $30 \mathrm{mph}$ who only mistakenly believes he is going $50 \mathrm{mph}$. His conduct shows us that he deserves some blame and may be dangerous, but such mistaken drivers can have no effect on the expected total injuries. Thus, their conduct is in the nature of an attempt rather than a substantive offense. ${ }^{50}$

It is this recognition that objective risks make the world worse that has prompted special rules to reduce such risks, such as those prohibiting driving fast past a schoolyard and those creating general endangerment offenses. What these offenses prohibit and punish is the creation of objective risks.

\footnotetext{
${ }^{50}$ A further argument for treating objective risks as results resides in the application of the causation doctrine. We would want the special causation requirements to be used to limit liability for creation of objective risks. To deny that objective risks are results would bar application of the causation requirements and produce improper liability results. Consider the actor who plans to dump toxic debris in an empty lot. The lot is next to a school, and the dumping will create a risk to the children that will result in endangerment liability if it the dumping is successful. But the actor, driving in the dead of night, takes a wrong turn. He thinks he is dumping by the school and creating the risk to the children, but in fact is dumping in an empty lot quite a distance away, which creates no risk to anyone. A freak tornado soon comes up, which picks up the contents of the distant lot and deposits it on the lot next to the school. Would we say that he should be held liable for endangerment? I think not. I think we would say that the results - the creation of the objective risk to the children - are too remote or accidental from his conduct. His liability ought to be in the nature of attempted endangerment.
} 


\section{E. Criminalization of Risk-Creation Offenses: The Results-Don't-Matter Scheme versus the Results-Matter Scheme}

The Model Penal Code is true to its subjectivist criminalization agenda and tries to minimize the significance of results. It explicitly drops the requirement that an objective risk be created. As the discussion above illustrates, its efforts are well obscured when it does so by criminalizing through reliance on its definitions of "recklessly" and "negligently." The Code is less obscure in its formulation of its general endangerment offense, which requires only that the actor "engage in conduct which places or may place another in danger ... ." ${ }^{51}$

Table 1 summarizes the criminalization and grading pattern for risks of causing another's death, as adopted by states following the Model Penal Code.

51 Model Penal Code $\S 211.2$. 
Table 1. The Model Penal Code Criminalization of Risk-Creation in Homicide Offenses:

By Result and Culpability

\begin{tabular}{|c|c|c|c|}
\hline $\begin{array}{l}\text { Culpability } \\
\text { Level: }\end{array}$ & $\begin{array}{c}\text { Subjective } \\
\text { risk-taking } \\
\text { (Recklessness) }\end{array}$ & $\begin{array}{l}\text { No subjective } \\
\text { risk-taking, } \\
\text { but culpable } \\
\text { inattentiveness } \\
\text { (Negligence) }\end{array}$ & $\begin{array}{c}\text { No culpable } \\
\text { inattentiveness } \\
\text { (No culpability) }\end{array}$ \\
\hline $\begin{array}{l}\text { Prohibited risk created, } \\
\text { resulting in death }\end{array}$ & $\begin{array}{c}\text { (1) } \\
\text { Manslaughter }{ }^{52} \\
\text { (Second-degree felony) }\end{array}$ & $\begin{array}{l}\text { (2) } \\
\text { Negligent homicide } \\
\text { (Third-degree felony) }\end{array}$ & (no liability) \\
\hline $\begin{array}{l}\text { Non-prohibited risk } \\
\text { created, } \\
\text { resulting in death }\end{array}$ & $\begin{array}{c}(3) \\
\text { Manslaughter }^{54} \\
\text { (Second-degree felony) }\end{array}$ & $\begin{array}{l}\text { (4) } \\
\text { Negligent homicide } \\
\text { (Third-degree felony) }\end{array}$ & (no liability) \\
\hline $\begin{array}{l}\text { Prohibited risk created, } \\
\text { no death resulting }\end{array}$ & $\begin{array}{c}\text { (5) } \\
\text { Endangerment }^{56} \\
\text { (misdemeanor) }\end{array}$ & $\begin{array}{c}(6) \\
\text { (no liability) }\end{array}$ & (no liability) \\
\hline $\begin{array}{c}\text { Non-prohibited risk (or } \\
\text { no risk) created, } \\
\text { no death resulting } \\
\end{array}$ & $\begin{array}{c}\text { (7) } \\
\text { Endangerment }^{57} \\
\text { (misdemeanor) }^{\text {misdemean }}\end{array}$ & $\begin{array}{c}(8) \\
\text { (no liability) }\end{array}$ & (no liability) \\
\hline
\end{tabular}

The column headings reflect the possible culpability levels as to risk under the Code: recklessness, negligence, and absence of culpability. The row headings reflect the variations of two result conditions: whether or not a prohibited risk was created and whether or not the risk (prohibited or not) came to fruition in a death.

The numbered boxes show the Code's assignment of liability and grading. Boxes (1) and (2) represent standard cases of reckless homicide and negligent homicide, respectively. Boxes (3) and (4) are cases where the culpability and result are the same as in boxes (1) and (2), respectively, but no prohibited risk is in fact created. As discussed previously, the absence of the prohibited risk is judged insignificant by the Code, which assigns liability identical to what it assigns when a prohibited risk is created (boxes (1) and (2)). The driver speeding past the schoolyard at 50 miles per hour, mistakenly believing the

${ }^{52} I d . \S \S 210.3(1)(\mathrm{a}), 210.3(2)$.

${ }^{53} I d . \S \S 210.4(1),(2)$.

${ }^{54} I d$. $\S \S 210.3(1)(\mathrm{a}), 210.3(2)$.

${ }_{55}^{55}$ Id. $\S \S 210.4(1),(2)$.

${ }^{56} I d . \S 211.2$.

${ }^{57} I d$. 
children are out for recess, is an example of box (3). ${ }^{58}$ The driver passing the schoolyard at $30 \mathrm{mph}$, who mistakenly believes he is going $50 \mathrm{mph}$ yet remains indifferent to whether the children are at recess, is an example of box (4). ${ }^{59}$ (In both cases we assume the driver kills an errant out-of-school child.)

In the case of endangerment but no death, boxes (5) and (7) similarly show identical liability assignments (as do boxes (6) and (8)), ignoring whether the actor's conduct in fact created a prohibited risk. ${ }^{60}$ As noted previously, the Model Penal Code's endangerment offense is explicit on the irrelevance of the occurrence of a prohibited risk: "A person commits a misdemeanor if he recklessly engages in conduct which places or may place another in danger ...." ${ }^{61}$ Thus, the toxic dumper who dumps next to a schoolyard, creating a risk of death to the children (box (5)), is subject to the same authorized punishment as the dumper who only believes, mistakenly, that there is a school next door and, therefore, is mistaken in his belief that he creates a prohibited risk (box (7)).

Manslaughter (boxes (1) and (3)) is graded more seriously than endangerment (boxes (5) and (7)), despite identical culpability (recklessness), presumably for the same reason that the Code drafters reluctantly allow a grading difference between murder and attempted murder: where death actually occurs, the case is more likely to get public attention, and the public would very much disapprove of a code's disregard of a resulting death.

This same dynamic may be at work in the Code's analogous treatment of negligent culpability cases, but here to a more dramatic effect: identical inattentiveness to creating a risk of death (in boxes (2), (4), (6), and (8)) is punished only in those cases where the risked death actually occurs (boxes (2) and (4)). This gives the occurrence of results its most dramatic effect: serving as a necessary requirement for any liability. In other words, not only does the Model Penal Code ignore the significance of results when it ought to be considered, but when it does consider results, it does so crudely, taking account of resulting harms but not resulting prohibited risks.

At the same time, the Code's pattern of liability and grading shows how little significance the drafters wish to give to results. Compare boxes (7) and (6). Where the actor creates no prohibited risk of death but just thinks he does (box (7)), he is punished. But where he actually creates a prohibited risk of death but is criminally inattentive to the risk — rather than consciously disregarding it — (box (6)), he is not punished. For the Model Code drafters, mistaken belief in the existence of a risk is more important than actually creating a prohibited risk of death through culpable inattentiveness.

\footnotetext{
58 See supra text accompanying notes 46-47.

59 See supra text accompanying note 51.

${ }^{60}$ See id.

61 Model Penal Code $\S 211.2$.
} 
It is this view that subjective risk-taking ought to be the only focus of criminal law that has caused both the regular overgrading of recklessness offenses where no risk in fact has been created and the regular undergrading - indeed, exclusion from liability — of culpable inattentiveness that results in the creation of a prohibited risk. A code that wishes to reflect the community's belief in the significance of results would provide a different allocation of liability and grading than that described in Table 1 . In Table 1's boxes (3) and (4), it would provide no liability (or, at most, the reduced liability of an impossible attempt) to reflect the absence of a prohibited risk. It would consider imposing liability in Table 1's box (6), to reflect the creation of a prohibited risk, albeit at a reduced grade than the liability in box (2), where not only the prohibited risk but also the prohibited harm is caused. It also would reduce liability in box (7) to at most that of an inchoate form-attempted endangerment, if such an offense is recognized - to reflect the absence of a prohibited risk.

Thus, where results are given significance, the pattern of liability and grading in homicide riskcreation would look more like that presented in Table 2:

Table 2. Homicide Risk-Creation Criminalization Pattern If Results Were Treated as Significant:

By Result and Culpability

\begin{tabular}{|c|c|c|c|}
\hline $\begin{array}{l}\text { Culpability } \\
\text { Level: } \\
\text { Result: }\end{array}$ & $\begin{array}{c}\text { Subjective } \\
\text { risk-taking } \\
\text { (Recklessness) }\end{array}$ & $\begin{array}{l}\text { No subjective } \\
\text { risk-taking, } \\
\text { but culpable } \\
\text { inattentiveness } \\
\text { (Negligence) }\end{array}$ & $\begin{array}{c}\text { No culpable } \\
\text { inattentiveness } \\
\text { (No culpability) }\end{array}$ \\
\hline $\begin{array}{l}\text { Prohibited risk created, } \\
\text { resulting in death }\end{array}$ & $\begin{array}{c}\text { (1) } \\
\text { Manslaughter } \\
\text { (second-degree felony) }\end{array}$ & $\begin{array}{c}\text { (2) } \\
\text { Negligent homicide } \\
\text { (third-degree felony) }\end{array}$ & (no liability) \\
\hline $\begin{array}{l}\text { Prohibited risk created, } \\
\text { no death resulting }\end{array}$ & $\begin{array}{c}\text { (3) } \\
\text { Reckless endangerment } \\
\text { (first-degree } \\
\text { misdemeanor) }\end{array}$ & $\begin{array}{c}\text { (4) } \\
\text { Negligent } \\
\text { endangerment } \\
\text { (second-degree } \\
\text { misdemeanor) } \\
\end{array}$ & (no liability) \\
\hline $\begin{array}{c}\text { Non-prohibited risk (or } \\
\text { no risk) created, } \\
\text { whether or not death } \\
\text { resulting }\end{array}$ & $\begin{array}{c}5) \\
\text { Attempted } \\
\text { endangerment } \\
\text { (second-degree } \\
\text { misdemeanor) }\end{array}$ & $\begin{array}{c}\text { (6) } \\
\text { (no liability) }\end{array}$ & (no liability) \\
\hline
\end{tabular}


Table 2's rows describe three categories of results: a prohibited risk resulting in the risked harm, the prohibited risk alone, and the absence of a prohibited risk. The Table's columns are the same as those in Table 1.

Culpable inattentiveness where death may occur, but no prohibited risk is created, ${ }^{62}$ Table 2 's box (6), is given no liability, ${ }^{63}$ in contrast to the Model Penal Code's imposition of liability in such a case (see Table 1, box (4)). In Table 2's box (4), culpable inattentiveness that results in a prohibited risk but no death is punished, in contrast to its exclusion from liability under the Model Penal Code (see Table 1, box (6)).

The grading of such a case in Table 2 follows the pattern established in boxes (1), (2), and (3): a one grade reduction from subjective risk-taking to culpable inattentiveness, as seen in box (1) versus box (2); and a two grade reduction where only a prohibited risk of death is created, rather than a death caused, as seen in box (1) versus box (3). ${ }^{64}$ Also note that in box (5), the grading of endangerment is reduced (from box (3)) where no prohibited risk is created. The Model Penal Code provides no such reduction. Compare Table 1, box (7).

While this article does not address the issue, one may, for a variety of reasons, conclude that endangerment offenses ought to be seriously limited. Thus, one might conclude that the criminal law ought not recognize the offenses of negligent endangerment and attempted endangerment (boxes (4) and (5), respectively) because such conduct falls below the level of minimum seriousness of conduct with which the criminal law should concern itself, even at the reduced level of second-degree misdemeanor shown on Table 2.

\section{SUMMARY AND CONCLUSION}

Current criminal law formulations fail to distinguish the rule of conduct question-What risks does the criminal law prohibit?-from the adjudication question-When is a particular violator's conscious disregard of, or his inattentiveness to, a risk in a particular situation sufficiently condemnable to deserve criminal liability? Instead, they typically provide only a provision that addresses the second question-by

\footnotetext{
62 Presumably the death results from a risk that is not prohibited.

${ }^{63}$ A jurisdiction that seeks to punish acted-upon culpability alone, as in inchoate offenses, might impose very reduced liability here, but there are few, if any, jurisdictions at the moment that punish such attempted negligent endangerment.

The case is analogous, in many ways, to that of the unknowingly justified actor, who similarly deserves no substantive liability but, rather, deserves at most inchoate liability based upon his culpability toward creating a prohibited risk. See generally Paul H. Robinson, Competing Theories of Justification: Deeds vs. Reasons, in Harm and Culpability 45-70 (A.T.H. Smith \& Andrew Simester eds., 1996).

${ }^{64}$ Obviously, a community's shared intuitions might call for a different discount rate for either or both reduced culpability or absent results. See generally Paul H. Robinson \& John M. Darley, Objectivist vs. Subjectivist Views of Criminality: A Study in the Role of Social Science in Criminal Law Theory, 18 Oxford J. Legal Stud. 409 (1998).
} 
defining reckless and negligent culpability — and fail to provide a rule of conduct provision to define a prohibited risk.

The use of the "recklessly" and "negligently" culpability definitions is problematic not only because it is an inadequate substitute for an explicit definition of a prohibited risk, but also because it has no application to risk-creation offenses that do not contain the terms "recklessly" or "negligently." In these latter cases, the codes fail to direct the factfinder to consideration of the factors relevant to determining whether a risk is prohibited: its likelihood of occurring, the extent of the harm threatened, and justifying circumstances, judged under an objective reasonable person standard.

Even more importantly, the use of the culpability definitions as the core of the offense definition has the effect of subjectivizing the definition of prohibited risks. ${ }^{65}$ What may be held "reckless" or "negligent" for one person may not be "reckless" or "negligent" for another person in the identical situation - an effect that strips case adjudications of their value in educating the community as to risks that the rules of conduct prohibit.

Current risk-creation offenses also are problematic because they make results-including the creation of a prohibited risk-irrelevant to criminal liability. Making results irrelevant is consistent with the Model Penal Code drafters' general view of the proper determinants of liability, but is inconsistent with the view of most state code drafters. Thus, while the Model Penal Code grades offenses without regard to whether a prohibited risk is created, most state codes logically would want to grade lower in the absence of a prohibited risk. Similarly, while the Model Penal Code grades actual endangerment and attempted endangerment the same, most state codes logically would want to grade the former greater than the latter. To the state code drafters, whether a prohibited risk was created would be as important as whether the actor was reckless or only negligent.

These two fundamental problems - the failure to distinguish conduct rules and adjudication rules and the confusion over the significance of results - are related. The Model Penal Code's general failure to distinguish conduct and adjudication rules made it less likely that state code drafters would notice the Model Code's subjectivization of risk and risk offenses. Thus, it obscured to state code drafters the fact that the Model Code formulations_-defining risk offenses to require only culpability ("recklessly caused" or "negligently caused") — conflict with most states' view that results should be given significance. If the Model Code had systematically segregated conduct and adjudication rules throughout, it would have been more obvious to state code drafters that the Model Code's formulation of risk-creation offenses was one that they could not accept. 
${ }^{65}$ The Model Penal Code uses the same individualizing language in the definitions of both "recklessly" and "negligently" (see Model Penal Code $§ 2.02(2)(c)$, (d), second sentence of each subsection), thus affecting all riskcreation offenses. 